\title{
Innovation Strategy in Slovak Forest Contractor Firms-A SWOT Analysis
}

\author{
Martina Štěrbová ${ }^{1}$, Erika Loučanová ${ }^{2}$, Hubert Paluš ${ }^{2, *}$, L'ubomír Ivan ${ }^{3}$ and Jaroslav Šálka ${ }^{1}$ \\ 1 Department of Economics and Management of Forestry, Technical University in Zvolen, T.G.Masaryka 24, \\ 96053 Zvolen, Slovakia; martina.sterbova1@gmail.com (M.S.); salka@tuzvo.sk (J.S.) \\ 2 Department of Marketing, Trade and World Forestry, Technical University in Zvolen, T.G.Masaryka 24, \\ 96053 Zvolen, Slovakia; loucanova@tuzvo.sk \\ 3 Headquarters, The University Forest Enterprise, Študentská 20, 96053 Zvolen, Slovakia; \\ lubomir.ivan@tuzvo.sk \\ * Correspondence: palus@tuzvo.sk; Tel.: +421-455-206-444
}

Academic Editors: Thomas J. Straka and Eric J. Jokela

Received: 21 March 2016; Accepted: 25 May 2016; Published: 31 May 2016

\begin{abstract}
The aim of the study is to determine the innovation strategy of contractor firms in the Slovak forestry service sector in the area of further innovation activities development. The strategy identification was based on the analysis of the strengths, weaknesses, opportunities and threats in this sector. The results indicate that weaknesses of contractor firms exceed their strengths and, considering the degree and importance of their impact, opportunities exceed identified threats. Based on these findings revealing the relations in the area of innovation activities of forestry service contractors, the "Strategy of Partnership" was suggested as the most suitable type of strategy. It can be concluded that such a form of grouping cooperation brings many benefits to contractors in the form of information availability, guidance, training, and management of conflicts, risks and uncertainty, which are associated with the innovation process.
\end{abstract}

Keywords: innovation; strategy; contractor firms; forestry service sector

\section{Introduction}

In the current economy, innovation ability and its application in practice can be considered as the basic assumption for the success of the enterprise in a market economy. Innovations constitute an important dynamic factor of any enterprise and a significant connecting bridge between the present and the future of any organisation and whole economies. The ability to generate innovations is a crucial condition for the competitiveness of all enterprises. Innovations represent a step forward, the opportunity to grow faster, better and smarter than surrounding competitors. If the enterprise wants to increase its innovation activity, it is important to seek all available sources and benefit from the factors that significantly affect innovation activities.

Innovation capacity is generally regarded as a main precondition for the competitiveness of all businesses. The changes in the business environment and the process of creation of the global market are increasingly demanded by customer requirements, the increase in supply and services, stronger market competition, technological development and the globalisation of business. In this context, the innovations represent means for managing these changes. They also have their particular position and importance in the forestry sector [1].

Forestry has traditionally been perceived as an economic activity, the aims of which are to establish and cultivate forests to produce timber. Forest management is defined as the process of planning and implementing practices focused on fulfilling relevant functions of the forests and meeting defined objectives [2]. According to Šišák [3], the traditional (conservative) concept of forest management does 
not only concern the forester; it concerns a wider social environment that involves forest management, including environmental concepts, opinions and activities. In recent years, the overriding role of forestry has been associated with the provision of a wide range of services. These services are provided by a community of forestry contractors consisting mostly of small- and medium-sized enterprises that do not own and use forest lands, but only provide and ensure the full range of forestry services, especially the extraction and transport of timber [4].

Paluš et al. [5] state that a specific characteristic of the forestry services market is the fact that the major forestry operations are externally outsourced instead of being carried out by forest owners and managers themselves. Nevertheless, in other sectors, it is more common that subsidiary activities are outsourced. Outsourcing of forestry services also became a common strategy in many larger Swedish forest companies [6]. Some companies procure only a few services from contractors, whereas other companies have chosen to outsource all their operations to contractors. Typically, these contractors, similar to Slovakia, are micro-companies with one or two machine units and less than nine employees [7].

Paluš et al. [5] also conclude that it is more profitable for forest owners to purchase forestry services through suppliers than to own and lease machinery. A reduction in economic risks, a decrease in bounded capital in machinery, paired with increased incitements for productivity development by paying contractors piecework rate [8], cost reduction and more rapid adjustments of their capacity level of current needs were identified as the main motives for outsourcing forestry services $[6,9]$. However, during the last 20 years, a decline in harvesting contractor profitability has been noted. When the work environment is perceived to be stressful and salaries low, recruiting competent machine operators also seems to be a growing problem [10]. Similar experiences have also been reported in Finland [11,12].

The innovation research within the extant forest sector is mainly focused on the primary and secondary wood industry [13-15]; there has been very little research among entrepreneurs in silviculture [2]. However, nowadays, more research attention is being paid towards innovation in the forest sector [16,17] and now it is developing into a solid research field [18]. Primarily, technological issues such as harvesting, extraction operations and transport are studied in detail [2]. Anderson [19] states that companies providing forestry services in Canada were heavily dependent on mills and equipment manufacturers to develop innovations. Stone et al. [20] state that Maine's logging industry can be highly innovative and they can play an important role in forestry industry innovation efforts; however, several barriers were also emphasised, for example lack of collaboration.

In the Slovak forestry service sector, the current mechanisation is old and worn out and does not meet the needs for the development of modern technology and has a negative impact on the environment. A lack of financial resources can be considered as the main cause of this situation [21]. Similar findings have also been reported from innovation research in the Czech Republic [22,23]. However, as Dobšinská et al. [24] argue, in comparison to the past, the conditions for the implementation of innovations in forestry have significantly improved and enterprises are looking for ways to draw financial support for the implementation of innovative projects.

These restraints open up the opportunities for many innovation activities, as the emphasis in the process of providing forestry services has been placed on quality. The basic elements of success are the innovations leading to the use of specific technologies that are perceived by the contractors as their competitive advantage. The innovations are regarded as an instrument that can improve their competitiveness and strengthen the development of the sector [25]. A strong competition pertaining to forestry service providers is partially forcing entrepreneurs to invest money in new advanced technologies [5]. They need to be continually renewed and innovated to be competitive over time. Emphasising this, it is very important that renewal is not incompatible with keeping the old traditions and characteristics of forestry [26]. It is quite obvious that the firms with modern technologies are able to more easily obtain working contracts [5]. 
On the other hand, being highly innovative carries risk and added costs that can potentially negatively affect performance because of a time delay. Investments in innovations may require cash outlays, which can negatively impact short-term profitability [26]. However, forest contracting firms that engage in risk-taking are more innovative. They are more able to take independent action and have a competitive advantage over rivals, achieving better results [27-30]. Nevertheless, the most that contractor companies are willing to invest in innovations under certain conditions is related to risk reduction. This means that the main part of investments $(50 \%-80 \%)$ will be paid back by the contract. They also prefer long-term-duration contracts based on long-term relationships between the parties [31]. Another characteristic feature of this market is that the supply of services exceeds demand. Moreover, the negotiating position of contractors is weak and there is also limited space to reach the terms that would effectively protect contractors from potential opportunistic behaviour of forest owners. Therefore, enormous innovations are not common in this sector. Usually, it is only a small adjustment of applied techniques and technologies for the specific requirements of each customer or working conditions [5]. In some cases, these innovations can be understood as the paradigm of innovation, when success is based on innovations leading to the use of specific technologies or a method that is not common in that particular situation [31,32].

In general, according to Hansen et al. [33], forestry represents a conservative and isolated field, with limited knowledge transfer, which is not able to invest enough in innovativeness and innovations. Nevertheless, it appears that forest entrepreneurs face the same realities and react in the same way as their counterparts in other sectors [34]. Culture change presents a significant opportunity within the industry to strive toward the improved development of new products, processes and business systems for improving the innovation performance of the enterprises in forestry. Klenk and Wyatt [35] argue that the strategy in the forestry sector should be focused on knowledge mobilisation that leads to innovations, which entails a level of engagement with partners that is creative and transformative rather than mainly informative. In the long term, it should create new avenues for innovation in this sector. Fazey et al. [36] state that the cooperation strategy representing a way to support the dissemination of knowledge and the implementation of innovation seems to mainly be a conceptual approach adopted between stakeholders representing the epistemological orientation of research collaboration. For the purpose of innovations development, Rametsteiner and Weiss [37] propose a more complex system view of innovation "as a complex non-linear process involving a range of players and different interactions", with the focus on the social elements of the system.

According to Nybakk et al. [26], social networking and learning orientation are key antecedents to innovativeness, and innovativeness is very important for obtaining high performance. Networking can increase innovative capacity and innovativeness among forestry contractors by providing new ideas and access to resources, and by knowledge transfer. Accordingly, investments in networking with local players brings advantages by gaining new ideas, concentrating on the main expertise and finding new and better ways to run a business.

Within the framework of cooperation strategy aimed at the opportunities of forestry contractor firms, it is possible to focus on different forms of clusters, such as the following [38]:

- Vertical production chain-groupings are downstream processing stages in the production chain

- Cluster of interconnected industries-the basis for groupings is four levels of related industries or groups of enterprises such as the production of finished products, equipment for production, special production inputs and follow-up services for production

- Regional cluster-a grouping of interconnected industries within a particular region and competitive sectors in world markets

- Industrial zone-a local concentration of small- and medium-sized enterprises

- Network-a specific form of relations between economic partners that is not based on the market, but on interdependence-cooperation 
- Innovation environment-a high concentration of industries of high-tech types with a particular synergy of economic and institutional factors.

Therefore, the aim of this paper is to define the innovation strategy of contractor firms in the Slovak forestry service sector in the area of innovation activities by identifying the internal and external environment in the form of strengths, weaknesses, opportunities and threats in this field.

\section{Materials and Methods}

In order to meet the objective of this study and to define the strategy of contractor firms in the Slovak forestry service sector in the area of innovations, a questionnaire survey was used. Contractor firms operating in the Slovak forestry sector represented the basic population of the survey. A collection of quantitative data was performed on a representative sample of 115 firms randomly selected from the available database of enterprises. It is an internal database of the Department of Economics and Management of Forestry at the Technical University in Zvolen. It was created in partnership with managers of the Organisational Unit of State Forests of the Slovak Republic, who provided contact lists of their suppliers. As the size of the population was known (21,694 firms), the minimum sample size (97) was determined according to the formula for determining the size of a random sample [39]. The confidence level was $95 \%$ and the confidence interval was $10 \%$.

The questionnaire, focused on the innovation behaviour of contractor firms in the Slovak forestry service sector, consisted of six series of closed, semi-open and open questions concerning the basic characteristics of the firm, machinery and technological equipment used, attitudes and opinions of managers related to environmental aspects of the business, level of implementation of innovations within timber harvesting and transport processes, fostering and impeding factors of innovation activities, possible establishment of new business, as well as personal evaluation and attitudes of respondents to innovation activities in the sector of forestry services as a whole.

The process of data collection included a combination of structured interviews personally carried out with managerial staff and distribution by regular mail and e-mail. All responses were registered in a database, checked for complexity and analysed quantitatively. For the purpose of this study, emphasis was placed on the fostering factors of innovations identified by the firms with innovation experience. Impeding factors, which restrain the implementation of innovations, were identified by firms without innovation experience. Respondents were allowed to select more than one factor from a list of possibilities. The number of the selection of individual fostering and impeding factors indicates their importance within the innovation process. SWOT analysis (Strengths, Weaknesses, Opportunities and Threats) was used as a tool to evaluate strengths, weaknesses, opportunities and threats [40], i.e., to evaluate the internal and external environment of contractor firms and rank them according to their importance. SWOT analysis is the most popular method for analytic modelling used in strategic analysis, which has previously been used in various areas of research, such as medicine by Willis et al., 2015 [41], logistics by Tavana et al. [42], and forest certification by Kurttila et al. [43]. It is used in the development and implementation of long-term strategies to achieve particular objectives and to evaluate alternative strategies in order to determine the best one for a given sector setting, as stated by Sevkli et al. [44] and Bull et al. [45]. Quantitatively evaluated data from the database represented the basis for this systematic analysis as they were focused on the characteristics of the key factors influencing the strategic position of enterprises. Utilising the quantitative information, the process of data collection in the SWOT analysis used the hybrid method [43]. Factors identified on the basis of the inductive-deductive method were divided into the internal and external environment of contractor firms. The internal environment evaluates strengths and weaknesses and the external environment evaluates opportunities and threat factors. Their importance is a quantitative measure of the proportion-identifying factor of all responders expressed as a percent. The synthesis of acquired factors of the SWOT analysis allowed for the characterisation of opportunities and the identification of realistic assumptions for future development. Once the quantitative data were assigned to the acquired factors, SWOT analysis represented a clear tool for the orientation in perception of the strategic position 
of the industry. SWOT analysis is a simple but effective tool in strategic planning that can be used by organisation to identify such factors [42]. These acquired and quantitatively evaluated factors in the SWOT analysis were subsequently used and assessed within the TOWS matrix (Threats, Opportunities, Weaknesses and Strengths matrix). As stated by Wu et al. [46], the TOWS matrix is an interactive matrix based on SWOT, and it is a method of systematically identifying relationships between factors of the SWOT analysis. Further, strategies are suggested based on this analysis. TOWS proposes the most suitable strategies, maximising Strengths and Opportunities, while minimising Weaknesses and Threats, and the positions that have to be established are decided in order of management [46], i.e., Strengths-Weaknesses and Opportunities-Threats. Their differences will be drawn on a TOWS matrix and the general strategy of the TOWS matrix can be identified. Using this matrix, it was possible to place contractor firms into one of the four quadrants according to their dominant features and to define the appropriate strategy (Figure 1).

\begin{tabular}{|l|c|c|}
\hline & Strengths (S) & Weaknesses (W) \\
\hline WO strategies & WO strategies \\
& $\begin{array}{c}\text { Leverage strengths to } \\
\text { maximize } \\
\text { opportunities } \\
\text { Attacking strategy }\end{array}$ & $\begin{array}{c}\text { Counter weaknesses through } \\
\text { exploiting opportunities } \\
\text { Build strengths for attacking strategy }\end{array}$ \\
\hline ST strategies & WT strategies \\
& $\begin{array}{c}\text { Leverage strengths to } \\
\text { minimize threats } \\
\text { Defensive strategy }\end{array}$ & $\begin{array}{c}\text { Counter weaknesses and threats } \\
\text { Build strengths for defensive strategy }\end{array}$ \\
\hline
\end{tabular}

Figure 1. TOWS matrix: strategic alternative of the SWOT analysis.

The TOWS matrix identifies various classes of strategies that follow on from a SWOT analysis: (1) those that link Strengths and Opportunities, SO Strategies for the attacking strategy; (2) those that link Weaknesses and Opportunities-this is potentially the most successful offensive strategy when it is appropriate to focus on innovation-WO Strategies to build strengths for the attacking strategy; (3) those that jointly focus on the Strengths and Threats-this is a strategy of alliance when investing in innovation through cooperation-ST strategies for a defensive strategy; (4) and those that arise from the joint assessment of Weaknesses and Threats-this is a defensive strategy, which will be invested in for supporting innovation strengths and eliminating risks-WT Strategies to build strengths for a defensive strategy, which is a strategy disinvestment when compromising changes are made, to minimise weaknesses and avoid risks [42]. Applying the TOWS matrix within the SWOT analysis identifies a general strategy, which will be modified for the conditions pertaining to the innovation strategy of contractor firms in the Slovak forestry service sector.

\section{Results}

Based on the results of the survey, according to the methodology, the internal and external environment was identified in the form of Strengths and Weaknesses as well as the Opportunities and Risks of innovation activities among the contractors of forestry services (Table 1). Their importance is a quantitative measure of the proportion-identifying factor of all respondents expressed as a percent. 
Table 1. SWOT analysis—innovative behaviour of contractor firms providing services in the Slovak forestry sector.

\begin{tabular}{|c|c|c|c|}
\hline Strengths (S) & $\%$ & Weaknesses (W) & $\%$ \\
\hline Sufficient current equipment & 16 & Lack of own financial resources & 61 \\
\hline Satisfactory operational results & 8 & High input costs & 11 \\
\hline \multirow{2}{*}{ Constant number of orders } & \multirow{2}{*}{1} & High operational costs & 8 \\
\hline & & Conservatism & 1 \\
\hline Total & 25 & Total & 81 \\
\hline Opportunities $(\mathrm{O})$ & $\%$ & Threats $(\mathrm{T})$ & $\%$ \\
\hline Availability of financial loans & 15 & Low price for services & 8 \\
\hline \multirow[t]{2}{*}{ State budget support programs } & \multirow[t]{2}{*}{4} & Unfavourable business environment & 4 \\
\hline & & Lack of work and uncertainty of future work & 3 \\
\hline \multirow{2}{*}{$\begin{array}{l}\text { Regional government and municipal support } \\
\text { programs }\end{array}$} & \multirow[b]{2}{*}{4} & Problematic tender procedures & 4 \\
\hline & & Strong competition & 4 \\
\hline EU support programs & 7 & Economic crisis & 1 \\
\hline Availability of information on innovations & 6 & Difficulties with obtaining a loan & 8 \\
\hline Forestry consultancy & 1 & Taxes and insurance payments & 8 \\
\hline Advisory services of other consultants & 4 & The risk of selling products or services & 7 \\
\hline Availability of skilled labour & 10 & Lack of skilled labour & 3 \\
\hline Possibilities for further education & 4 & Lack of information on sales markets & 2 \\
\hline Cooperation with other contractors in the field & 7 & $\begin{array}{l}\text { Lack of information on possible new products } \\
\text { and services }\end{array}$ & 4 \\
\hline $\begin{array}{l}\text { Cooperation with companies of a different } \\
\text { focus }\end{array}$ & 5 & $\begin{array}{l}\text { Lack of information on possibilities of support } \\
\text { in implementing innovations }\end{array}$ & 5 \\
\hline Cooperation with suppliers & 12 & Nature and environmental & \\
\hline Cooperation with customers & 15 & legislation & 5 \\
\hline $\begin{array}{l}\text { Cooperation with authorities and other public } \\
\text { institutions }\end{array}$ & 4 & Forest Act & 4 \\
\hline Cooperation with research institutions & 2 & Trade Licensing Act & 5 \\
\hline & & Labour law & 5 \\
\hline & & Technical standards and regulations & 4 \\
\hline & & Cooperation with customers & 5 \\
\hline & & Cooperation with public institutions & 4 \\
\hline & & Cooperation with research institutions & 1 \\
\hline Total & 100 & Total & 94 \\
\hline
\end{tabular}

In the field of innovations, contractor firms can see their strengths, especially in the current equipment sufficiency, satisfactory economic results and stable revenues from contracts. Weaknesses of innovation activities for the contractors are mainly the lack of funds, high input costs of innovation, high operational costs and conservatism of the sector. The identified opportunities can mainly be found in the form of various support programs and cooperation. In general, there were many more threats than opportunities identified; however, the firms do not perceive these threats to be as significant as the opportunities. The risks, in particular, concern bureaucracy, lack of skilled labour, low prices for delivered services, etc.

Figure 2 highlights the fact that contractor firms in the Slovak forestry service sector in the area of innovation activity state that negative factors in the external environment dominate over factors in the internal environment. In the external environment, opportunities outweigh threats; in the internal environment, weaknesses outweigh strengths. The link between the internal and external environment of forestry services contractors is illustrated in Figure 2. 


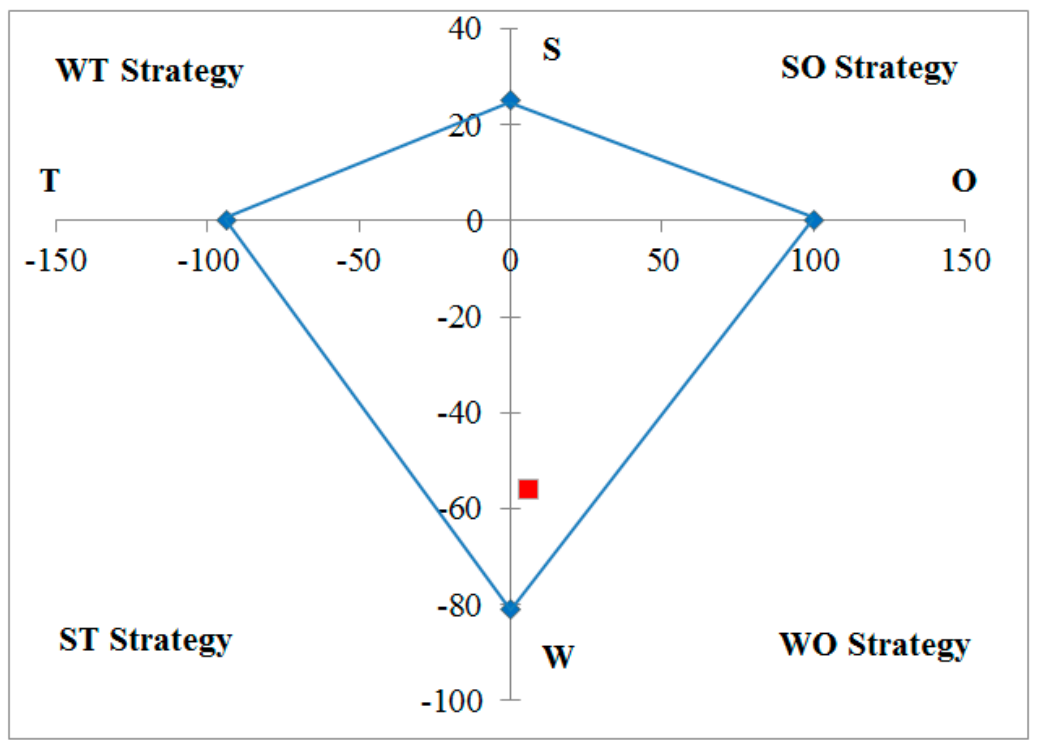

Figure 2. SWOT analysis—strategic alternatives for forestry contractor firms.

As indicated above, despite the number of risks that affect the implementation of innovations among the contractors in terms of their influence, they are less serious than the identified opportunities which outweigh the risks by $6 \%$ in the external environment, i.e., Opportunities-Threats $=100 \%-94 \%=6 \%$. On the contrary, in the internal environment, weaknesses outweigh the strengths of innovations by $56 \%$, i.e., Strengths-Weaknesses $=25 \%-81 \%=-56 \%$. The choice of the strategy can be determined by plotting the relationship between strengths and weaknesses as well as the opportunities and threats in the TOWS matrix (Figure 3).

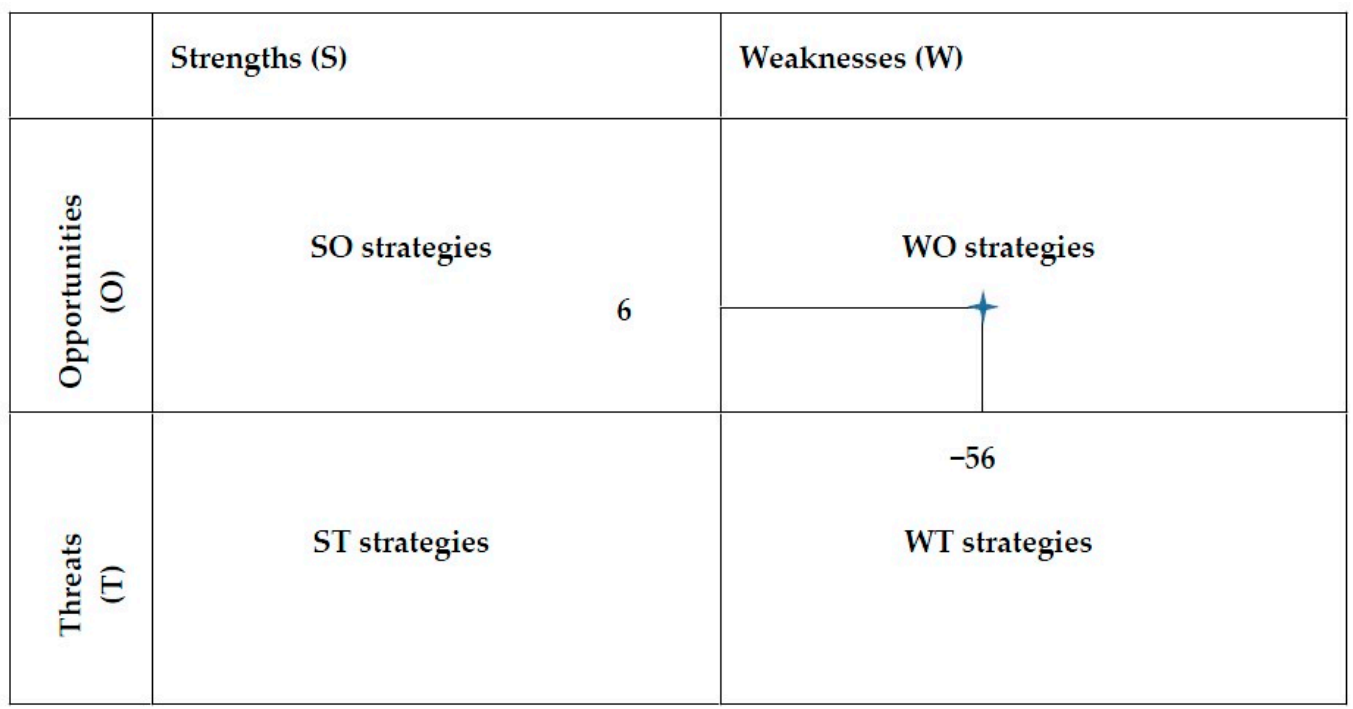

Figure 3. TOWS matrix of forestry contractor firms.

A general strategy is therefore recommended: WO Strategies to build strengths for an attacking strategy that links Weaknesses and Opportunities, i.e., counter weaknesses through exploiting opportunities. The TOWS matrix proposes a WO-an alliance strategy as a suitable option for contractor firms in the Slovak forestry services sector. The alliance strategy identified within the TOWS matrix is suitable for businesses that are dominated by weaknesses. In order to eliminate them, the firms have to make use of alternative opportunities offered by the external environment. 
At the same time, they need to monitor weaknesses and avoid risks. Although the difference between opportunities and threats $(6 \%)$ can seem insignificant, taking into account the number of threats in this sector, it can be considered justified. Therefore, the alliance strategy is recommended rather than the attacking strategy.

\section{Discussion}

Based on the results of our study, the recommended innovation strategy for contractor firms in the Slovak forestry service sector is a WO strategy. It is appropriate for businesses that are dominated by weaknesses. The most appropriate way to eliminate weaknesses related to innovations is to utilise the opportunities the contractors identified primarily, such as availability of financial loans, support programs at different levels, cooperation with all players and availability of skilled labour, etc. These findings are also consistent with the study of Lekovič [47], who identified the main barriers to innovation. An important opportunity to eliminate weaknesses is associated with a lack of information and knowledge of innovations. This is also consistent with the statement that the existing innovation knowledge base does not provide good guidance for managers to develop their innovation pathways [48]. Despite these findings, Hansen and Nybakk [49] suggest an increased focus on customers and competitors accompanied by careful dissemination and use of information about each across the firm as an advisable path. Such cooperation can be defined as a common denominator for the development of innovations. It can be recommended to strengthen existing cooperation through the creation of clusters of enterprises and to fully utilise the benefits derived from clustering cooperation such as information, innovation, cooperation, consultation and advocacy, etc. The cluster nurtures the existing strengths and growth potential of functionally interrelated and geographically co-located groups of specialised firms cross-sectorally linked by technologies, markets or value chains [50]. Štěrbová et al. [32] state that the regions of Banská Bystrica, Poprad and Košice can be considered as preferred potential regions for the creation of forestry contractor clusters in Slovakia. Considering that the entrepreneurs have little knowledge about the concept of clustering, it can be concluded that the most important measure to support a possible cluster would be the provision of information among the entrepreneurs in the regions [51].

The strategy of cooperation within the industry clusters aimed at the choice of innovation strategy should be focused within a specialised expertise, where the strategy is focused on specialisation of an early innovation initiation in the segment. This strategy requires unique skills in the subject field and continuous innovation in the improvement of expertise. Depending on the type of business, the risks are connected to the fact that specialisation will become a universal concept [38].

Based on the results of our research, the most appropriate strategy is the innovation strategy of cooperation aimed at the opportunities of contractors within specialisation oriented expertise of innovations in the combination of the network and the vertical production chain, where the companies prefer a cluster of suppliers-to-customers chains based on the inputs and outputs, as they represent economic partners for the contractors.

Our findings are also supported by other studies of successful types of innovations in contractor firms in Slovakia. Štěrbová and Šálka [52] conducted 10 case studies focused on the mapping of innovation processes in the enterprises with an emphasis on the fostering and impeding factors of this process. The research results show that vertical and horizontal cooperation within the sector is very important.

The results point out a similar development of forestry innovations in Slovakia that is focused on cooperation in innovations and is aimed at the strategy of alliances. This is similar to the case in some other countries, based on the results of Klenk and Wyatt [9], who view the strategy of innovation development in the forestry sector in the long-term involvement of partners to model knowledge co-production, leading to innovation and problem-solving in the sector. The basic idea of the alliance strategy for the development of innovation in this sector is also a result of other studies, e.g., Fazey et al. [36], Rametsteiner and Weiss [37], Ellefson et al. [53], Raitzer [54], Scarascia-Mugnozza et al. [55], and Klenk and Wyatt [35]. 


\section{Conclusions}

It can be concluded that innovation activities in the market of forestry services still remain relatively low as a result of insufficient financial resources for innovations. The need for interventions either by the state or the EU in the form of supporting mechanisms appears to be the biggest innovation opportunity in the market for forestry services. This mainly stems from the fact that the most significant weaknesses of the innovation activities of forestry contractor firms were identified within the framework of ensuring the financial side of innovations. Most businesses do not have a sufficient amount of their own funds to cover such high input and operational costs associated with the innovation process. The contractors can see the strengths of innovations especially in the current equipment sufficiency, satisfactory economic results and stable revenues gained from contracts. On the other hand, low prices for services delivered, the risk of selling these services, an excessive tax burden and the high degree of bureaucracy are perceived as major threats.

The results point out the fact that weaknesses prevail over the strengths in the forestry contractor market in Slovakia. As part of the external environment, given the scale and severity of the impact, the opportunities outweigh the risks. Based on these relationships, the alliance strategy-WO-appears to be the most favourable strategy option in the field of innovation activities. The cooperation strategy requires the monitoring and elimination of weaknesses and risk avoidance while maintaining the use of alternative opportunities offered by the external environment. There are many benefits on following from this form of cooperation groupings such as availability of information, consultation and advocacy, and training as well as conflict, risk and uncertainty management associated with the innovation process.

Acknowledgments: The authors would like to thank the Scientific Grant Agency of the Ministry of Education, Science, Research and Sport of the Slovak Republic and the Slovak Academy of Sciences. This paper was elaborated within the framework of Grant project 1/0473/16 "Dynamics and Determinants of Wood Based Products Market in the Slovak Republic", and the Cultural and Educational Agency of the Ministry of Education, Science, Research and Sport of the Slovak Republic, Grant No. 017TU Z-4/2015 "Modernisation and Internationalisation of Forest Policy Education at Technical University in Zvolen". The paper originated in terms of the Project "Centre of Excellence: Adaptive forest ecosystems", based on the support of SOP Research and Development funded by the European Regional Development Fund under contract No. 262201200006 and No. 26220120049.

Author Contributions: Martina Štěrbová and Erika Loučanová collected data and prepared Materials and Methods and Results as parts of the article. The introduction section was written by Hubert Paluš and Jaroslav Šálka. L'ubomír Ivan helped with the literature review and all authors contributed to Discussion and Conclusions sections.

Conflicts of Interest: The authors declare no conflict of interest.

\section{References}

1. Lacko, M.; Šálka, J. Podnikatel'ské a inovačné správanie lesných podnikov v SR. In Financovanie 2003; Technical University in Zvolen: Zvolen, Slovakia, 2003; pp. 67-75. (In Slovak)

2. Nybakk, E.; Lawrence, A.; Weiss, G. Innovation in Forest Management for New Forest Owner Types-A Literature review. Available online: http://facesmap.boku.ac.at/index.php/library2/doc_ download /478-background-paper-of-working-group-2-innovation-in-forest-management-for-newforest-owner-types-a-literature-review (accessed on 12 April 2016).

3. Šišák, L. Potenciál inovací v lesním hospodářství versus tradice a právní prostředí v České republice. In Stav a perspektivy inovací v lesním hospodářství; Česká zemědělská univerzita: Prague, Czech Republic, 2007; pp. 28-33. (In Czech)

4. Bouriaud, L.; Kastenholz, E.; Fodrek, L.; Karaszewski, Z.; Mederski, P.S.; Rimmler, T. Policy and market-related factors for innovation in forest operations enterprises. In Innovation in Forestry-Territorial and Value Chain Relationships; Weiss, G., Ed.; CAB International: Oxon, UK, 2011; pp. 276-293.

5. Paluš, H.; Kaputa, V.; Parobek, J.; Šupín, M.; Šulek, R.; Fodrek, L. Trh s lesníckymi službami; Technical University in Zvolen: Zvolen, Slovakia, 2011; p. 45. (In Slovak) 
6. Ager, B. The Rationalization and humanization of forest work 1900-2011 and forward; Swedish University of Agricultural Sciences: Umeå, Sweden, 2012; p. 196.

7. Häggström, C.; Kawasaki, A.; Lidestav, G. Profiles of forestry contractors and development of the forestry-contracting sector in Sweden. Scand. J. For. Res. 2013, 28, 395-404. [CrossRef]

8. Norin, K. Forestry-Contractor Services-Buying and Selling: A Discussion of Business Approaches that Support Developments in Logging Systems; Skogforsk: Uppsala, Sweden, 2002; p. 31.

9. Ambrušová, L.; Šulek, R. Factors influencing forest owners and manager's decision making about forestry services in logging-transport process. For. J. 2014, 60, 177-184.

10. Bergquist, E. Why do Forest Machine Operators Leave the Forest Industry?; Swedish University of Agricultural Sciences: Umeå, Sweden, 2009; p. 35.

11. Rummukainen, A.; Dahlin, B.; Penttinen, M.; Selby, A.; Mikkola, J. Challenges to the forest machine business as a result of global economic change. In Forest, Wildlife and Wood Sciences for Society Development; Czech University of Life Sciences Prague: Prague, Czech Republic, 2009; pp. 461-473.

12. Penttinen, M.; Rummukainen, A.; Mikkola, J. Profitability, liquidity and solvency of wood harvesting contractors in Finland. Small-Scale For. 2011, 10, 211-229. [CrossRef]

13. Hansen, E.N.; Nybakk, E.; Bull, L.; Crespell, P.; Jélvez, A.; Knowles, C. A multinational investigation of softwood sawmilling innovativeness. Scand. J. For. Res. 2011, 26, 278-287. [CrossRef]

14. Stendahl, M.; Roos, A. Antecedents and barriers to product innovation-A comparison between innovating and non-innovating strategic business units in the wood industry. Silva Fennica. 2008, 42, 659-681. [CrossRef]

15. Nybakk, E. Learning orientation, innovativeness and financial performance in traditional manufacturing firms: A higher-order structural equation model. Int. J. Innov. Manag. 2012, 16, 1-28. [CrossRef]

16. Hansen, E.N. The role of innovation in the forest products industry. J. For. 2010, 108, 348-353.

17. Weiss, G.; Pettenella, D.; Ollonqvist, P.; Slee, B. Innovation in Forestry: Territorial and Value Chain Relationships; CAB International: Oxfordshire, UK, 2011; p. 331.

18. Rametsteiner, E.; Hansen, E.N.; Niskanen, A. Introduction to the special issue on innovation and entrepreneurship in the forest sector. For. Policy Econ. 2006, 8, 669-673. [CrossRef]

19. Anderson, F. A comparison of innovation in two Canadian forest services support industries. For. Policy Econ. 2006, 8, 674-682. [CrossRef]

20. Stone, I.J.; Benjamin, J.G.; Leahy, J. Applying innovation theory to Maine's logging industry. J. For. 2011, 109, 462-469.

21. Ambrušová, L.; Marttila, J. Comparison of Outsourced Operations in Wood Procurement in Finland and Slovakia; Finnish Forest Research Institute: Vantaa, Finland, 2012; p. 22.

22. Pudivítrová, L.; Jarský, V. Inovační aktivity v lesním hospodářství České Republiky. Zpr. Lesn. Výzkumu 2011, 56, 320-328. (In Czech)

23. Jarský, V. Analysis of the sectoral innovation system for forestry of the Czech Republic. Does it even exist? For. Policy Econ. 2015, 59, 56-65. [CrossRef]

24. Dobšinská, Z.; Sarvašová, Z.; Šálka, J. Changes of innovation behaviour in Slovakian forestry. The Annals of the "Stefan cel Mare"; University of Suceava. Fascicle of The Faculty of Economics and Public Administration: Suceava, Romania, 2010. Available online: http://www.seap.usv.ro/annals/arhiva/ANNALS\%20vol.10,nr. 2(12),2010\%20fulltext.pdf (accessed on 12 February 2015).

25. Posavec, S.; Šporčić, M.; Antonić, M.; Beljan, K. Innovation fostering-key factor of development in Croatian forestry. Šumar. List 2011, 135, 234-256.

26. Nybakk, E.; Crespell, P.; Hansen, E.N.; Lunnan, A. Antecedents to forest owner innovativeness: An investigation of thenon-timber forest products and services sector. For. Ecol. Manag. 2009, 257, 608-618. [CrossRef]

27. Sikora, A.T.; Nybakk, E.; Panwar, R. The effect of entrepreneurial and learning orientations on financial performance in a transition economy: Evidence from forest contracting firms in southern Poland. Scand. J. For. Res. 2015, 31, 119-125. [CrossRef]

28. Wiklund, J. The sustainability of the entrepreneurial orientation-performance relationship. Entrep. Theory Pract. 1999, 24, 37-48.

29. Rauch, A.; Wiklund, J.; Lumpkin, G.T.; Frese, M. Entrepreneurial orientation and business performance: Cumulative empirical evidence. Entrep. Theory Pract. 2009, 33, 761-787. [CrossRef]

30. Sikora, A.T.; Nybakk, E. Rural development and forest owner innovativeness in a country in transition: Qualitative and quantitative insights from tourism in Poland. For. Policy Econ. 2012, 15, 3-11. [CrossRef] 
31. Paluš, H.; Loučanová, E.; Kaputa, V. Kontrakty a manažment rizika inovačného procesu poskytovatel'ov lesníckych služieb na Slovensku. Zpr. Lesn. Výzkumu 2015, 60, 8-13. (In Slovak)

32. Šterbová, M.; Loučanová, E.; Šálka, J.; Paluš, H. The regional innovation paradoxes of forestry contractors firms in Slovakia. In Investments to Forests and Forest based Production: Scientific Book; WoodEMA: Zagreb, Croatia, 2014; pp. 33-57.

33. Hansen, E.N.; Nybakk, E.; Panwar, R. Innovation Insights from North American Forest Sector Research: A Literature Review. Forests 2014, 5, 1341-1355. [CrossRef]

34. Drolet, S.; LeBel, L. Forest harvesting entrepreneurs, perception of their business status and its influence on performance evaluation. For. Policy Econ. 2010, 12, 287-298. [CrossRef]

35. Klenk, N.L.; Wyatt, S. The design and management of multi-stakeholder research networks to maximize knowledge mobilization and innovation opportunities in the forest sector. For. Policy Econ. 2015, 61, 77-86. [CrossRef]

36. Fazey, I.; Bunse, L.; Msika, J.; PInke, M.; Preedy, K.; Evely, A.C.; Lambert, E.; Hasting, E.; Morrie, S.; Reed, M.S. Evaluating knowledge exchange in interdisciplinary and multi-stakeholder research. Glob. Environ. Chang. 2014, 25, 204-220. [CrossRef]

37. Rametsteiner, E.; Weiss, G. Innovation and innovation policy in forestry: Linking innovation process with systems models. For. Policy Econ. 2006, 8, 691-703. [CrossRef]

38. Kovalčík, M.; Loučanová, E.; Sarvašová, Z.; Zaušková, A. Regionálny governance a lesníctvo. In Governance v Lesníctve; Národné lesnícke centrum: Zvolen, Slovakia, 2009; pp. 44-66. (In Slovak)

39. U.S. Air Force; Ross, K.C. Air University Sampling and Surveying Handbook: Guidelines for Planning, Organizing and Conducting Surveys; University Press of the Pacific: Honolulu, HI, USA, 2006; p. 104.

40. Lesáková, D. Strategický Marketingový Manažment; NETRI: Bratislava, Slovakia, 2004; p. 264. (In Slovak)

41. Willis, D.S.; Thurston, M. Working with the disabled patient: Exploring student nurses views for curriculum development using a SWOT analysis. Nurse Educ. Today 2015, 35, 383-387. [CrossRef] [PubMed]

42. Tavana, M.; Zareinejad, M.; Di Caprio, D.; Kaviani, M.A. An integrated intuitionistic fuzzy AHP and SWOT method for outsourcing reverse logistics. Appl. Soft Comput. 2016, 40, 544-557. [CrossRef]

43. Kurttila, M.; Pesonen, M.; Kangas, J.; Kajanus, M. Utilizing the analytic hierarchy process (AHP) in SWOT analysis-A hybrid method and its application to a forest-certification case. For. Policy Econ. 2000, 1, 41-52. [CrossRef]

44. Sevkli, M.; Oztekin, A.; Uysal, O.; Torlak, G.; Turkyilmaz, A.; Delen, D. Development of a fuzzy ANP based SWOT analysis for the airline industry in Turkey. Expert Syst. 2012, 39, 14-24. [CrossRef]

45. Bull, J.W.; Jobstvogt, N.; Böhnke-Henrichs, A.; Mascarenhas, A.; Sitas, N.; Baulcomb, C.; Lambini, C.K.; Rawlins, M.; Baral, H.; Zähringer, J.; et al. Strengths, Weaknesses, Opportunities and Threats: A SWOT analysis of the ecosystem services framework. Ecosyst. Serv. 2016, 17, 99-111. [CrossRef]

46. Wu, F.-G.; Ma, M.-Y.; Chang, R.-H. A new user-centered design approach: A hair washing assistive device design for users with shoulder mobility restriction. Appl. Ergon. 2009, 40, 878-886.

47. Lekovič, B. Entrepreneurs perception of barriers for development of innovation: Analysis of data from northern Bačka country. Megatrend Rev. 2013, 10, 95-114.

48. Hansen, E.N.; Bull, L. An illustration of lessons for forest sector researchers and managers from current new product development research. J. For. Prod. Bus. Res. 2010, 7, 1-7.

49. Hansen, E.N.; Nybakk, E. When innovativeness determines market orientation: The forest sector and the Great Recession. BioProd. Bus. 2016, 1, 1-12.

50. Rimmler, T.; Coppock, R.; Oberwimmer, R.; Pirc, A.; Posavec, S.; Weiss, G. How to support firm competitiveness in timber industries? Clusters as policy means in four European countries. In Innovation in forestry: Territorial and value chain relationships; CAB International: Oxfordshire, UK, 2011; pp. 101-117.

51. Nonic, D.; Nedeljkovic, J.; Rankovic, N.; Marinkovic, M.; Glavonjic, P.; Weiss, G. Analysis of factors influencing cluster establishment in the Timok forest area in Serbia. Austrian J. For. Sci. 2012, 129, $202-227$.

52. Štěrbová, M.; Šálka, J. Successful Types of Innovations of Contractor Firms in Slovak Forestry-Results of Case Studies. In ISeC, Proceedings of the International Virtual Conference, Bratislava Slovakia, 2015; pp. 262-268.

53. Ellefson, P.V.; Kilgore, M.A.; Skog, K.E.; Risbrudt, C.D. Forest Products Research and Development Organizations in a Worldwide Setting: A Review of Structure, Governance, and Measures of Performance of Organizations Outside the United States; General Technical Report FPL-GTR-172. Department of Agriculture, Forest Service, Forest Products Laboratory: Madison, FL, USA, 2007; p. 106. 
54. Raitzer, D.A. Assessing the impact of policy-oriented research: The case of CIFOR's influence on the Indonesian pulp and paper sector. World Dev. 2010, 38, 1506-1518. [CrossRef]

55. Scarascia-Mugnozza, G.; Bajocco, S.; Nardi, P.; DI Matteo, G. Report on the Mapping and Characterisation of Existing Funding Programmes and Research Capacities. Available online: http:/ / www.foresterra.eu/pdfs / FORESTERRA_Deliverable2+4_draft.pdf (accessed on 10 March 2016).

(c) 2016 by the authors; licensee MDPI, Basel, Switzerland. This article is an open access article distributed under the terms and conditions of the Creative Commons Attribution (CC-BY) license (http:/ / creativecommons.org/licenses/by/4.0/). 